\title{
Identification of No. 8 spoilage bacteria and study on biological properties of areca taro
}

\author{
Shang Feifei ${ }^{1}$, Xie Yuhua ${ }^{1}$, Chen Baoqiu ${ }^{1}$, Li Lili $^{1}$, Fan Linlin ${ }^{1}$, Lv xiaohua ${ }^{2}$, Chen Yuntang, ${ }^{2, *}$ Duan Zhenhua ${ }^{1, *}$ \\ ${ }^{1}$ School of Food and Bioengineering/Institute of Food Science and Engineering Technology, Hezhou university, 548299, Hezhou, \\ Guangxi, China \\ ${ }^{2}$ Isotope Institute Co., Ltd., Henan Academy of Science / Henan Key Laboratory of Nuclear Agriculture, Henan province Irradiation \\ processing engineering technology research center , 450015, Zhengzhou, Henan, China
}

\begin{abstract}
You should leave $8 \mathrm{~mm}$ of space above the abstract and $10 \mathrm{~mm}$ after the abstract. The heading Abstract should be typed in bold 9-point Times. The body of the abstract should be typed in normal 9-point Arial in a single paragraph, immediately following the heading. The text should be set to 1 line spacing. The abstract should be centred across the page, indented $17 \mathrm{~mm}$ from the left and right page margins and justified. It should not normally exceed 200 words. In order to explore the effects of fungus infestation on areca taro during cold storage period, a black morphologic fungus (No. 8) was isolated and identified as Curvularia lunata by morphological observation and 18sRNA gene sequencing. The study on its biological properties showed that the growth and development temperature of Curvularia lunata were $15-40{ }^{\circ} \mathrm{C}$, the optimal temperature was $25-30{ }^{\circ} \mathrm{C}$, the optimal $\mathrm{pH}$ was $6-8$, the optimal light condition was natural light, the optimal carbon source was sorbitol, maltodextrin and mannitol, and the optimal nitrogen source was glycine. The optimum germination temperature, $\mathrm{pH}$ and humidity of conidia were $25-40^{\circ} \mathrm{C}, 6-9$ and $100 \%+$ water drop, respectively, under the promotion of $40 \%$ areca taro solution. The aim of this study was to provide a theoretical basis for the prevention and treatment of areca taro rotting in cold storage period.
\end{abstract}

\section{Introduction}

Areca taro, also known as lipu taro, fuding taro and fragrant taro, is a high starch aquatic vegetable belonging to araceae taro[1].After removing the rough skin, the stem block is milky white with brown or purple areca grain. The pulpis sweet and fragrant, and becomes more intense after cooking.

The diseases and the species and quantity of spoilage bacteria during the growth of areca taro directly affect the storage effect after harvest. He Yan and others [2] systematically investigated the occurrence characteristics and rules of taro diseases and insects in Hezhou, Guangxi and found that taro was seriously harmed by taro blight, taro soft rot, taro blotch, spodoptera litura, taro aphid and underground pests during planting. Pan Feng-rong and others [3] discussed a variety of field control measures through the occurrence characteristics of areca taro diseases and insect pests. Chen Xue-rong and others[4] found in the control of taro anthracnose and blight caused by seed dressing with bactericide that 300 times liquid dressing with $58 \%$ metalaxyl manganese zinc wettable powder had a better disease prevention effect and could effectively improve the commerciality and yield of taro. Liu Qiong-ying and others [5] found in the efficacy test on the control of taro blight that $68 \%$ Redomir manganese zinc water dispersible granule, $72 \%$ metalaxyl manganese and zinc wettable powder, and $58 \%$ metalaxyl manganese zinc wettable powder all had significant effects on the control of taro blight, but $68 \%$ Redomir manganese zinc water dispersible granule had the best effect. Jiao Qingqing and others[6] found that $72 \%$ frost urea $\cdot$ manganese zinc wettable powder had better control effect in the control of Taro blight form Taixing-xianghe. In conclusion, the current research on taro disease is still mainly focused on the damage and control measures of pests and diseases during the planting period, but less attention is paid to the related research on the spoilage microorganisms that cause the decay of areca taro during the storage period.

In this study, a series of spoilage molds were isolated from the rotten areca taro during cold storage. Among them, the typical black mold No. 8 was taken as the research object to identify and study the biological properties of this fungus, in order to provide theoretical basis for the prevention and treatment of rotten disease and preservation methods of areca taro during storage.

\section{Materials and methods}

\subsection{Materials and reagents}

No. 8 spoilage strain was isolated and purified from rotten areca taro collected from HeZhouJinTai Grain and

\footnotetext{
* Corresponding author1: Chyt1015@163.com

*Corresponding author2: dzh65@126.com
} 
Oil Market. PDA culture medium was purchased from Guangdong Huankai Biotechnology Co., Ltd. Basic medium 1 (yeast extract $1 \mathrm{~g}$, peptone $2 \mathrm{~g}, \mathrm{KH}_{2} \mathrm{PO}_{4} 1 \mathrm{~g}$, AGAR $20 \mathrm{~g}$, water $1000 \mathrm{~mL}$, puted into $250 \mathrm{~mL}$ triangle flask, $150 \mathrm{~mL}$ per flask, routine sterilization for $15 \mathrm{~min}$ ). Basic medium 2 (without peptone, the preparation was the same as that of basic medium 1). $40 \%$ areca taro culture solution $(200 \mathrm{~g}$ peeled stems of areca taro added with $1000 \mathrm{~mL}$ water were heated to boil for half an hour, and then added the heating water to $1000 \mathrm{~mL}$ again, filtered in a triangular flask while hot by multilayer gauze, and sterilized at $121{ }^{\circ} \mathrm{C}$ for 20 minutes). Sodium hydroxide, hydrogen chloride and other reagents are produced by Sinopharm Chemical Reagents Company. The reagents such as carbon source and nitrogen source were all analytical pure.

\subsection{Instruments and equipment}

Microscope (Motic China Group Co., Ltd), DL-CJ-2N type super clean table (Beijing Donglianhaer Instrument Manufacturing Co., Ltd.), Vertical pressure steam sterilizer 510C (Chongqing Yamatuo Technology Co., Ltd.), PH070A drying oven/incubator (Shanghai Yiheng Scientific Instrument Co., Ltd.), Mold incubator (Shanghai Boxun Industrial Co., Ltd.), PXZ type (multi-segment programming) intelligent artificial climate box (Ningbo Jiangnan Instrument Factory), Precision $\mathrm{pH}$ meter (Shanghai Hongyi Instrument Meter Co., Ltd.).

\subsection{Morphological characteristics observation and preliminary identification of pathogenic bacteria}

Using the slide culture method, PDA culture solution was dropped on the sterile glass slides in the plane petri dishes. After condensation, it was inoculated from the surrounding areas and covered with the cover glass. Then, an appropriate amount of sterile water was dropped into the petri dishes, and the plates were covered, and the incubations were placed at $28^{\circ} \mathrm{C}$ for 2-3 days to observe and describe the morphological characteristics of each pathogen under the light microscope [7].

\subsection{Genomic DNA extraction, PCR amplification and sequencing}

Sangon Bioengineering (Shanghai) Co., Ltd. was commissioned to conduct DNA extraction and sequencing.The identified gene sequences were analyzed with NCBI database for homology analysis to determine the species and genus relationship of pathogenic bacteria.

\subsection{The affect on the growth, sporulation and relative quantity of mycelium by different temperatures}

The small bacterial blocks were transplanted into the PDA plate with a $5 \mathrm{~mm}$ diameter perforator, and cultured at 5,10 , $15,20,25,30,35$ and $40^{\circ} \mathrm{C}$ with a gradient of $5^{\circ} \mathrm{C}$ for 4 days. The "+" method was used to measure the diameter of the colony, and the average value was taken. The colony was observed and the thickness and density of mycelium were visually estimated [8]. After the test, adding $10 \mathrm{~mL}$ sterile water to each petri dish, the conidia with a sterile spoon was gently scraped to make the suspension fluid into a snowball observation counting plate $\left(25^{*} 16\right)$. The sporulation amount was measured under a microscope, and each counting plate was repeated for 3 times. The blood count yield was calculated as follows:

Spore production quantity $($ cells $/ \mathrm{mL})=($ spore number in 80 cells $) / 80 \times 400 \times 1000 \times$ Diluted multiples

\subsection{Effects of different pH values on the growth and sporulation of pathogenic bacteria and relative quantity of mycelium}

With $1 \mathrm{moL} / \mathrm{L} \mathrm{NaOH}$ and $1 \mathrm{moL} / \mathrm{L} \mathrm{HCL}, \mathrm{pH}$ of PDA culture medium was adjusted into 1, 2, 3, 4, 5, 6,7, 8, 9, 10,11 , respectively. After routine sterilization, the PDA medium was poured on the plate. The inoculated plate was placed in a $28{ }^{\circ} \mathrm{C}$ incubator. After 4 days, the colony diameter, mycelium relative amount and sporulation amount were measured according to the method of 1.5 , and each treatment was repeated 3 times.

\subsection{Influence of different light treatments on spoilage bacteria}

The same bacteria block were inoculated on PDA plate and cultured under 5 different light conditions, including continuous light, natural light (12h light dark alternation), 12h UV light (12h UV $+84 \mathrm{~h}$ natural light), 6h UV light (6h UV $+90 \mathrm{~h}$ natural light) and complete darkness. The growth indexes were measured according to the method of 1.5 , and each treatment was repeated 3 times.

\subsection{Utilization of different carbon and nitrogen sources by spoilage bacteria}

Nine kinds of carbon were tested (Table 4) and five kinds of nitrogen were tested (Table 5). $1 \mathrm{~g}$ of each carbon and nitrogen were added to the basic medium 1 and 2, then the basic medium 1 and 2 were sterilized for $10 \mathrm{~min}$, poured into petri dishes, then transplanted into small bacterial blocks, and incubated at $28^{\circ} \mathrm{C}$ for 4 days [8]. The colony diameter and sporulation yield were measured according to the method of 1.5 , and the growth was observed. Each treatment was repeated for 3 times.

\subsection{Effects of culture medium, temperature, $\mathrm{pH}$ and humidity on spore germination}

\subsubsection{Influence of culture medium on spore germination}

The amplified culture petri dishes were added with $10 \mathrm{~mL}$ sterile water and $40 \%$ culture solution of taro, conidia were scraped off, and conidia suspension with a 
concentration of about $5^{*} 105 / \mathrm{mL}$ was prepared. The conidia suspension was dropped and evenly coated on a clean glass slide (about 50 conidia per unit field of vision) and placed in a moisturizing petri dish. The spores were cultured at different temperatures ranging from $5^{\circ} \mathrm{C}$ to $45^{\circ} \mathrm{C}$, and the germination of spores was examined under microscope after $24 \mathrm{~h}$. Each treatment was repeated three times. Conidial germination rate was calculated as follows [8-9]:

Conidial germination rate $(\%)=($ Number of spores per unit field of view)/(Total number of spores per unit field of view) $\times 100 \%$

\subsubsection{Influence of temperature on spore germination rate}

The spore suspension was prepared with $40 \%$ taro culture solution and dropped on clean slides. The spore suspension was cultured at the above 9 temperatures for $2 \mathrm{~h}$ and the germination was examined under microscope. Each treatment was repeated three times.

\subsubsection{Effect of $\mathrm{pH}$ on spore germination rate}

The $\mathrm{pH}$ value of the culture solution of $40 \%$ taro was adjusted to $1 \sim 11$, a total of 11 grades, and the corresponding spore suspension was prepared according to the grade. The spore suspension was coated on the moisturizing slide and placed in a clean petri dish to moisturize and germinate for 3 repetitions and cultured at $28^{\circ} \mathrm{C}$ for $2 \mathrm{~h} \mathrm{[9]}$, and the observation contents were the same as 1.9.1.

\subsubsection{Affection on spore germination rate by humidity}

The spore suspension above was coated on the slide, dried in the shade and put into an incubator with humidity of $60 \%$, $70 \%, 80 \%, 90 \%, 100 \%, 100 \%$ + water drops. The incubator was cultured at $28^{\circ} \mathrm{C}$, and the germination was examined under microscope every $2 \mathrm{~h}$, with 3 replicates for each treatment.

\section{Results and analysis}

\subsection{Morphological characteristics obse-rvation and gene identification results}
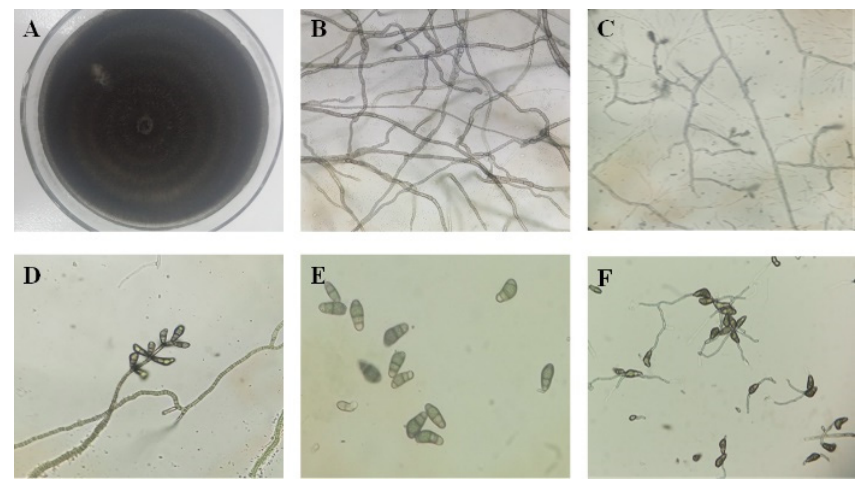

A. Colony morphological characteristics; B substrate mycelium; C basal surface mycelium; D conidia and conidia pedicel; E conidia; F spore

Fig. 1. Morphological observation of No. 8 spoilage bacteria

No. 8 pathogen was growing well. The colony was round, composed of concentric circles with black and white spacing, with neat edges, and was navy blue to black. The substrate mycelium was very well developed, initially navy blue, and gradually black to varying degrees, with septum and many branches. The basal surface mycelium was white, single or several root clusters, had septum, and be piled pressure after with the black conidia increase, not easy to see. Conidia pedicels was brown, single or branched, had sporulation at the apex. The conidia are gryish-brown, fusiform and crescent in shape. The cells are divided into different cells by three septa. The third cell from the base up was larger, darker in color, and the cells at both ends were relatively shallow. The results were highly similar to Zheng Nan's description of Curvularia lunata [10]. The conidia germinated, and the buds grown from both ends of the conidia, and the buds grown preferentially from the base. By 18sRNA identification, the similarity between the gene fragment and the gene registration number JN941608.1 reached 99\%. Combined with morphological observation, the strain was identified as Curvularia lunata.

\subsection{Study results of biological characte- ristics on No.8 spoilage bacterium (Cur- vularia lunata) of Areca taro}

\subsubsection{Effects of different temperatures on mycelial growth, sporulation yield and relative quantity of mycelia}

The results in Table 1 showed that the hypha of Curvularia lunata could grow at $15-40{ }^{\circ} \mathrm{C}$, and the optimal growth temperature was $25-30{ }^{\circ} \mathrm{C}$. The mycelia did not grow at a temperature lower than $15^{\circ} \mathrm{C}$, and the growth ability of mycelia was weakened higher than $30^{\circ} \mathrm{C}$. Conidium began to generate at $15{ }^{\circ} \mathrm{C}$, the optimal temperature of spores is $20-30{ }^{\circ} \mathrm{C}$, and $30{ }^{\circ} \mathrm{C}$ was highest for sporulation yield, up to $9.58 \times 10^{5}$. The low temperature and high temperature were not suitable for the growth, development and reproduction of this strain.

\subsubsection{Effects of different $\mathrm{pH}$ on mycelial growth, sporulation and relative quantity of mycelia}

The results in Table 2 showed that Curvularia lunata could grow in the $\mathrm{pH}$ range of 4-11, and the optimum $\mathrm{pH}$ value for mycelium growth was 6-8, and corresponding sporulation yield was also the highest. When $\mathrm{pH}$ was lower than 4, the mycelia did not grow at all, and when $\mathrm{pH}$ was higher than 8 , the mycelia of pathogenic bacteria slowly tended not to grow.Conidia began to form at a $\mathrm{pH}$ of 4 , and the optimal $\mathrm{pH}$ for sporulation was 7.It could be 
seen that the growth, development and reproduction of Curvularialunata tended to be neutral and alkaline environment (Table 2).

Table 1. Effects of different temperatures on the growth and sporulation yield of Curvularia lunata

\begin{tabular}{|c|c|c|c|c|c|c|c|c|}
\hline \multirow{2}{*}{ Biological characteristics } & \multicolumn{9}{|c|}{ Temperature ( ${ }^{\circ} \mathrm{C}$ ) } \\
\cline { 2 - 10 } & $\mathbf{5}$ & $\mathbf{1 0}$ & $\mathbf{1 5}$ & $\mathbf{2 0}$ & $\mathbf{2 5}$ & $\mathbf{3 0}$ & $\mathbf{3 5}$ & $\mathbf{4 0}$ \\
\hline Colony diameter (mm) & 0 & 0 & 27.93 & 46.00 & 57.00 & 83.47 & 21.50 & 1.63 \\
\hline $\begin{array}{c}\text { Significance of difference } \\
\text { Relative amount of } \\
\text { mycelium }\end{array}$ & - & - & + & ++ & +++ & +++ & + & + \\
\hline $\begin{array}{c}\text { sporulation yield (1x10 } 5 \\
\text { Significance of difference }\end{array}$ & 0 & 0 & 0.53 & 5.68 & 7.32 & 9.58 & 0.38 & 0.15 \\
\hline & $\mathrm{abE}$ & $\mathrm{abE}$ & $\mathrm{bcC}$ & $\mathrm{bBC}$ & $\mathrm{aAB}$ & $\mathrm{aA}$ & $\mathrm{bcC}$ & $\mathrm{cdD}$ \\
\hline
\end{tabular}

Table 2. Effects of different $\mathrm{pH}$ on the growth and sporulation yield of Curvularia lunata

\begin{tabular}{|c|c|c|c|c|c|c|c|c|c|c|c|}
\hline \multirow{2}{*}{$\begin{array}{c}\text { Biological } \\
\text { characteristics }\end{array}$} & \multicolumn{11}{|c|}{ pH } \\
\hline & 1 & 2 & 3 & 4 & 5 & 6 & 7 & 8 & 9 & 10 & 11 \\
\hline $\begin{array}{l}\text { Colony diameter } \\
(\mathrm{mm})\end{array}$ & 0 & 0 & 0 & 51.17 & 55.57 & 58.17 & 58.33 & 57.33 & 56.33 & 54.50 & 53.00 \\
\hline $\begin{array}{l}\text { Significance of } \\
\text { difference }\end{array}$ & $\mathrm{dD}$ & $\mathrm{dD}$ & $\mathrm{dD}$ & $\mathrm{cC}$ & $\mathrm{bcB}$ & $\mathrm{abA}$ & $\mathrm{abA}$ & $\mathrm{abA}$ & $\mathrm{bcB}$ & $\mathrm{cdC}$ & $\mathrm{cdC}$ \\
\hline $\begin{array}{l}\text { Relative amount of } \\
\text { mycelium }\end{array}$ & - & - & - & + & ++ & +++ & +++ & +++ & ++ & ++ & + \\
\hline $\begin{array}{l}\text { sporulation yield } \\
\left(1 \times 10^{5}\right)\end{array}$ & 0 & 0 & 0 & 2.25 & 2.55 & 3.07 & 3.17 & 2.35 & 1.75 & 1.37 & 1.07 \\
\hline $\begin{array}{l}\text { Significance of } \\
\text { difference }\end{array}$ & $\mathrm{dD}$ & $\mathrm{dD}$ & $\mathrm{dD}$ & $\mathrm{adBC}$ & $\mathrm{bB}$ & $\mathrm{abA}$ & $\mathrm{abA}$ & $\mathrm{acBC}$ & $\mathrm{bcC}$ & $\mathrm{cdC}$ & $\mathrm{bdC}$ \\
\hline
\end{tabular}

\subsubsection{Effect of light on the growth of Curvularia lunata}

Table 3. Effects of different light on the growth of Curvularia lunata

\begin{tabular}{|c|c|c|c|}
\hline $\begin{array}{c}\text { Light } \\
\text { processing }\end{array}$ & $\begin{array}{c}\text { Colony } \\
\text { diameter } \\
(\mathbf{m m})\end{array}$ & $\begin{array}{c}\text { Sporulation } \\
\text { yield } \\
\left(\mathbf{1} \times \mathbf{1 0}^{\mathbf{5}} \mathbf{A} / \mathbf{m L} \mathbf{)}\right.\end{array}$ & $\begin{array}{c}\text { Relative } \\
\text { amount of } \\
\text { mycelium }\end{array}$ \\
\hline $\begin{array}{c}\text { Continuous } \\
\text { light }\end{array}$ & $62.33 \mathrm{adA}$ & $2.70 \mathrm{cC}$ & ++ \\
\hline Natural light & $61.50 \mathrm{bdB}$ & $5.30 \mathrm{aA}$ & +++ \\
\hline $\begin{array}{c}\text { Ultraviolet } \\
\text { (uv) } 12 \mathrm{~h}\end{array}$ & $61.00 \mathrm{bdBC}$ & $3.93 \mathrm{bB}$ & ++ \\
\hline $\begin{array}{c}\text { Ultraviolet } \\
\text { (uv) 6 h }\end{array}$ & $57.50 \mathrm{cC}$ & $1.97 \mathrm{dD}$ & + \\
\hline $\begin{array}{c}\text { Complete } \\
\text { darkness }\end{array}$ & $55.17 \mathrm{adD}$ & $2.20 \mathrm{cCD}$ & + \\
\hline
\end{tabular}

The results in Table 3 showed that the clods of Curvularia lunata were inoculated in the center of the plate and cultured under five different light conditions. The colony diameters were all large, but there was no significant difference between natural light and $12 \mathrm{~h}$ ultraviolet light. The hypha diameter of continuous light was the largest, the second was the light from the darkness alternation and the highest sporulation yield was $5.3 \times 10^{5} / \mathrm{mL}$. The colony diameters of complete darkness had the smallest diameter. The colony diameter and sporulation yield of $12 \mathrm{~h} \mathrm{UV}$ irradiation were better than that of $6 \mathrm{~h} \mathrm{UV}$ irradiation, and proper amount of UV irradiation could promote the growth of Curvularia lunata. According to the results of colony diameter and sporulation yield, light conditions of light dark alternation was more suitable for the growth, develop-ment and reproduction of Curvularia lunata.

\subsubsection{Utilization of different carbon and nitrogen sources by Curvularia lunata}

Table 4. Utilization of different carbon sources by Curvularia lunata

\begin{tabular}{|c|c|c|c|}
\hline $\begin{array}{c}\text { Carbon } \\
\text { source }\end{array}$ & $\begin{array}{c}\text { Colony } \\
\text { diameter } \\
\mathbf{( m m})\end{array}$ & $\begin{array}{c}\text { Sporulation } \\
\text { yield }(\mathbf{1} \times \mathbf{1 0} \\
\mathbf{A} / \mathbf{m L})\end{array}$ & $\begin{array}{c}\text { Relative } \\
\text { amount of } \\
\text { mycelium }\end{array}$ \\
\hline Maltodextrin & $70.00 \mathrm{acB}$ & $4.18 \mathrm{acF}$ & +++ \\
\hline Mannitol & $69.50 \mathrm{acC}$ & $5.95 \mathrm{eE}$ & +++ \\
\hline Sucrose & $54.50 \mathrm{efF}$ & $38.67 \mathrm{bB}$ & + \\
\hline Glucose & $54.33 \mathrm{efF}$ & $36.42 \mathrm{cC}$ & + \\
\hline Gum Arabic & $65.67 \mathrm{bdD}$ & $3.38 \mathrm{adG}$ & ++ \\
\hline $\begin{array}{c}\text { Soluble } \\
\text { starch }\end{array}$ & $65.83 \mathrm{bcD}$ & $41.33 \mathrm{aA}$ & ++ \\
\hline Lactose & $64.67 \mathrm{cdD}$ & $34.83 \mathrm{abD}$ & ++ \\
\hline D-Fructose & $60.67 \mathrm{eE}$ & $4.05 \mathrm{fF}$ & ++ \\
\hline Sorbitol & $71.00 \mathrm{abA}$ & $3.08 \mathrm{gG}$ & +++ \\
\hline
\end{tabular}

According to the results in Table 4, there were significant differences in the carbon sources required by the growth stage and the conidia production stage of Curvularia 
lunata. During mycelium growth, sorbitol, maltodextrin and mannitol, as carbon sources, could effectively promote mycelium growth, followed by soluble starch, gum acacia, lactose, and the worst were sucrose and glucose. During spore production, soluble starch, sucrose and glucose were carbon sources to promote spore production, followed by lactose, but maltodextrin, mannitol, gum Arabic, Dfructose and sorbitol were worst. Sorbitol produced the least amount of spores.

Table 5. Utilization of different Nitrogen sources by Curvularia lunata

\begin{tabular}{|c|c|c|c|}
\hline $\begin{array}{c}\text { Nitrogen } \\
\text { source }\end{array}$ & $\begin{array}{c}\text { Colony } \\
\text { diameter } \\
(\mathbf{m m})\end{array}$ & $\begin{array}{c}\text { Sporulation } \\
\text { yield }\left(\mathbf{1} \times \mathbf{1 0}^{\mathbf{5}}\right. \\
\mathbf{A} / \mathbf{m L})\end{array}$ & $\begin{array}{c}\text { Relative } \\
\text { amount of } \\
\text { mycelium }\end{array}$ \\
\hline Glycine & $54.17 \mathrm{acC}$ & $3.05 \mathrm{abA}$ & + \\
\hline Methionine & $54.67 \mathrm{abC}$ & $1.82 \mathrm{acC}$ & + \\
\hline $\begin{array}{c}\text { Ammonium } \\
\text { nitrate }\end{array}$ & $60.00 \mathrm{bB}$ & $1.22 \mathrm{cC}$ & ++ \\
\hline L-histidine & $67.17 \mathrm{aA}$ & $2.45 \mathrm{acB}$ & +++ \\
\hline $\begin{array}{c}\text { Ammonia } \\
\text { water }\end{array}$ & $5.00 \mathrm{dD}$ & $0.00 \mathrm{dD}$ & - \\
\hline
\end{tabular}

The results in Table 5 showed that L-histidine was used as the nitrogen source for the mycelia of Curvularia lunata growing the fastest, followed by ammonium nitrate, glycine and ammonium nitrate were slower, and the bacteria could not use ammonia water.Glycine was the nitrogen source with the highest sporulation yield, followed by L-histidine.

\subsection{Effects of different conditions on spore germination rate of Curvularia lunata}

\subsubsection{Effects of different culture solution and temperature on spore germination}

According to the results in Table 6, conidia of Curvularia lunata also had a good germination effect in distilled water, but it was weaker than that in $40 \%$ areca taro solution, that is, $40 \%$ areca taro solution promoted the conidia germination of this bacterium. The conidia could germinate at $5-45^{\circ} \mathrm{C}$, and the optimal germination temperature was $25-40^{\circ} \mathrm{C}$.In addition, it was found that the conidia of Curvularialunata had strong germination ability. Even if it was cultured for a short time (2h) at a low temperature $\left(5^{\circ} \mathrm{C}\right)$, it could also have a very high germination rate, which was also an important reason for the gradual infection of areca taro by this bacterium in the process of cold storage.

\subsubsection{Effect of $\mathrm{pH}$ on spore germination}

According to the results in Table 7, conidia of Curvularia lunata could germinate at $\mathrm{pH}$ 3-11 after 2 hours, and the optimal $\mathrm{pH}$ was 6-9. The germination rate was the highest when the $\mathrm{pH}$ was $7-8$, and it did not germinate at all when the $\mathrm{pH}$ was less than 3 , while the germination decreased when the $\mathrm{pH}$ was higher than 9 . When the $\mathrm{pH}$ value was less than 3 , it still did not germinate after 4 hours. The germination rate of other conidia that could germinate at $2 \mathrm{~h}$ was nearly $100 \%$. The relative germination length was the longest when the $\mathrm{pH}$ value was 6-9. Therefore, the optimal $\mathrm{pH}$ value for conidia germination was 6-9.

\subsubsection{Effect of humidity on spore germination rate}

The results in Table 8 showed that different humidity and culture time had significant effects on conidia germination. The germination rate of conidia increased gradually with the humidity, and the greater the humidity, the better the germination effect of conidia. When there was condensation, the germination rate was the best, even if it was cultured for $2 \mathrm{~h}$, the germination rate could reach $100 \%$. At the same time, with the extension of culture time, the germination rate was higher and higher.Therefore, the optimal germination humidity of conidia o Curvularia lunata was $100 \%$ + water drop.

Table 6. Effects of culture solution and temperature on spore germination

\begin{tabular}{|c|c|c|c|c|c|c|c|c|c|}
\hline Biological characteristics & \multicolumn{9}{|c|}{ Temperature $\left({ }^{\circ} \mathrm{C}\right)$} \\
\cline { 2 - 10 } & $\mathbf{5}$ & $\mathbf{1 0}$ & $\mathbf{1 5}$ & $\mathbf{2 0}$ & $\mathbf{2 5}$ & $\mathbf{3 0}$ & $\mathbf{3 5}$ & $\mathbf{4 0}$ & $\mathbf{4 5}$ \\
\hline Sterile water (24h) & - & + & + & + & ++ & +++ & +++ & ++ & + \\
\hline $40 \%$ Areca taro solution (24h) & + & ++ & ++ & +++ & +++ & +++ & +++ & +++ & ++ \\
\hline $40 \%$ Areca taro solution(2h) & + & + & + & ++ & +++ & +++ & +++ & +++ & ++ \\
\hline
\end{tabular}

Note: Eye observation of spore germination could be divided into 3 levels $(+,++,+++)$ according to growth length. "-" refers to short mycelium, which is the same in the following table.

Table 7. Effect of $\mathrm{pH}$ on spore germination

\begin{tabular}{|c|c|c|c|c|c|c|c|c|c|c|c|}
\hline \multirow[t]{2}{*}{ Biological characteristics } & \multicolumn{11}{|c|}{$\mathbf{p H}$} \\
\hline & 1 & 2 & 3 & 4 & 5 & 6 & 7 & 8 & 9 & 10 & 11 \\
\hline $2 \mathrm{~h}$ conidia germination rate $(\%)$ & 0 & 0 & 62.22 & 67.16 & 72.92 & 80.48 & 91.38 & 90.90 & 81.82 & 70.00 & 64.29 \\
\hline Significance of difference & $\mathrm{fF}$ & $\mathrm{fF}$ & $\mathrm{eE}$ & $\mathrm{adD}$ & $\mathrm{cC}$ & $\mathrm{acB}$ & $\mathrm{abA}$ & $\mathrm{aA}$ & $\mathrm{bB}$ & $\mathrm{cC}$ & $\mathrm{dD}$ \\
\hline 4h conidia germination rate $(\%)$ & 0 & 0 & 100 & 100 & 100 & 100 & 100 & 100 & 100 & 100 & 100 \\
\hline
\end{tabular}




\begin{tabular}{|l|l|l|l|l|l|l|l|l|l|l|l|}
\hline Relative germination length & - & - & + & + & ++ & +++ & +++ & +++ & +++ & ++ & ++ \\
\hline
\end{tabular}

Table 8. Effect of different humidity on spore germination

\begin{tabular}{|c|c|c|c|c|c|c|}
\hline \multirow{2}{*}{ Biological characteristics } & \multicolumn{6}{|c|}{ Humidity(\%) } \\
\cline { 2 - 7 } & $\mathbf{6 0}$ & $\mathbf{7 0}$ & $\mathbf{8 0}$ & $\mathbf{9 0}$ & $\mathbf{1 0 0}$ & $\mathbf{1 0 0}+\mathbf{d e w}$ \\
\hline 2h conidial germination rate(\%) & $0 \mathrm{bB}$ & $0 \mathrm{bB}$ & $0 \mathrm{bB}$ & $0 \mathrm{bB}$ & $0 \mathrm{bB}$ & $100 \mathrm{aA}$ \\
\hline 4h conidial germination rate(\%) & $0 \mathrm{fF}$ & $0.12 \mathrm{eE}$ & $0.36 \mathrm{dD}$ & $1.24 \mathrm{cC}$ & $18.64 \mathrm{abB}$ & $100 \mathrm{aA}$ \\
\hline 6h conidial germination rate(\%) & $2.12 \mathrm{adF}$ & $10.64 \mathrm{eE}$ & $11.0 \mathrm{acD}$ & $17.64 \mathrm{abC}$ & $26.45 \mathrm{bB}$ & $100 \mathrm{aA}$ \\
\hline 8h conidial germination rate(\%) & $10.67 \mathrm{eE}$ & $16.0 \mathrm{adD}$ & $25.32 \mathrm{cC}$ & $36.62 \mathrm{acB}$ & $40.13 \mathrm{abB}$ & $100 \mathrm{aA}$ \\
\hline 10h conidial germination rate(\%) & $15.86 \mathrm{dC}$ & $30.55 \mathrm{bA}$ & $50.78 \mathrm{cB}$ & $71.36 \mathrm{aA}$ & $89.54 \mathrm{abA}$ & $100 \mathrm{aA}$ \\
\hline
\end{tabular}

\section{Conclusion}

The compound infection of multiple fungi is the main cause of areca taro's mildew and decay during storage. According to colony morphology, microscopic observa-tion and gene sequencing, the strain was identified as Curvularia lunata. Curvularia lunata is the main pathog-en causing leaf spot disease, but there are differences due to different parasitic environments and biological characteristics of plants. The biological characteristics of Curvularia lunata showed that the growth and development temperature and $\mathrm{pH}$ were 15 $45^{\circ} \mathrm{C}$ and $3-11$, the optimum temperature was $25-35{ }^{\circ} \mathrm{C}$, the optimum $\mathrm{pH}$ was $6-8$, the optimum light condition was natural light, the optimum carbon source was dextrin, mannitol, D-sorbitol, and the optimum nitrogen source was glycine, but ammonia water was not available.Conidia of this fungus could also germinate in low temperature water. $40 \%$ areca taro solution could significantly promote the germination of conidia. The optimal germination temperature was $25-40{ }^{\circ} \mathrm{C}$, the optimal $\mathrm{pH}$ value was 3-9, and the optimal humidity was $100 \%+$ water drop. The humidity had a significant effect on spore germination.

\section{Acknowledgements}

This study was supported by The National Natural Science Foundation of China (No. 31860458) and The Natural Science Foundation of Guangxi Province (No. 2017JJA130645Y)

\section{References}

1. A. Mecke, I. Lee, J.R. Baker jr., M.M. Banaszak Holl, B.G. Orr, Eur. Phys. J. E 14, 7 (2004) Sun Da-yang, Shang Fei-fei, Pan Zhong-tian, et al. , Effect of electron beam irradiation on storage of areca taro.Food and Machinery 36,8(2020)

2. Pan Feng-rong, Yang Cong-yun, Tan Quan-shu, et al.,Occurrence characteristics and control measures of taro disease and insect. Soil and Fertilizer Plant Protection 1,2 (2005)

3. He Yan,Occurrence characteristics and control measures of pests and diseases of taro in hezhou. Plant
Protection in Guangxi 18,2(2005)

4. Chen Xue-rong, Wu Wei, Chang Ya-yun, et al., Research on control effect of different fungicides on anthrax and blight of taro. Modern Agricultural Science and Technology,2(2015)

5. Liu Qiong-ying, Hu Jia-hua, Chen Shen-feng, et al.,Effect of $68 \%$ leidomir manganese zinc water dispersive granules on control of taro blight. Guangdong Agricultural Sciences,8(2008)

6. Jiao Qing-qing, Chen Xue-rong, Qin Xiao-ping, et al.,Effects of several antimicrobial agents on the control of Phytophessia blight in Taixing. Jiangsu Agricultural Sciences,42,10(2014)

7. Ruan Hua-fang,Identification of Fusarium fungi. Journal of Inner Mongolia Agriculture and Animal Husbandry College, 1(1983)

8. Yan Mei-xin, Liao Wang-jiao, Yuan Gao-qing et al.,Studies on biological characteristics of Trichoderma echinospora during storage of water chestnut rot.Southwest China Journal of Agricultural Sciences 23, 6(2010)

9. Liang Jun, Lai Chuan-ya, Huang Jian-ping, etal., Study on the biological characters of Cryptomyces solanum.Journal of Guangxi Agricultural University 14, 4(1995) 